\title{
Correction to: Mitochondrial Dynamics in SARS-COV2 Spike Protein Treated Human Microglia: Implications for Neuro-COVID
}

\author{
Erin Clough ${ }^{1} \cdot$ Joseph Inigo ${ }^{2}$. Dhyan Chandra ${ }^{2} \cdot$ Lee Chaves $^{1}$. Jessica L. Reynolds ${ }^{1} \cdot$ Ravikumar Aalinkeel $^{1}$. \\ Stanley A. Schwartz ${ }^{1}$. Alexander Khmaladze ${ }^{3}$. Supriya D. Mahajan ${ }^{1}$ (I)
}

Published online: 11 December 2021

(c) Springer Science+Business Media, LLC, part of Springer Nature 2021

\section{Correction to: Journal of Neuroimmune Pharmacology https://doi.org/10.1007/s11481-021-10015-6}

In the published article "Mitochondrial Dynamics in SARSCOV2 Spike Protein Treated Human Microglia: Implications for Neuro-COVID. Clough E, Chean KT, Inigo J, Tubbesing KE, Chandra D, Chaves L, Reynolds JL, Aalinkeel R, Schwartz SA, Khmaladze A, Mahajan SD. J Neuroimmune Pharmacol. 2021 Oct 2:1-15. https://doi.org/10.1007/ s11481-021-10015-6."

Author names Chean KT and Tubbesing KE needed to be deleted from the list of authors at their request.

The Editorial Office of Journal of Neuroimmune Pharmacology has approved this correction. The corresponding author apologizes for any inconvenience that it may have caused.
The correct Authors list should be: Clough E, Inigo J, Chandra D, Chaves L, Reynolds JL, Aalinkeel R, Schwartz SA, Khmaladze A, Mahajan SD.

And the article should now be cited as Mitochondrial Dynamics in SARS-COV2 Spike Protein Treated Human Microglia: Implications for Neuro-COVID. Clough E, Inigo J, Chandra D, Chaves L, Reynolds JL, Aalinkeel R, Schwartz SA, Khmaladze A, Mahajan SD. J Neuroimmune Pharmacol. 2021 Oct 2:1-15.

The original article has been corrected.

Publisher's Note Springer Nature remains neutral with regard to jurisdictional claims in published maps and institutional affiliations.
The original article can be found online at https://doi.org/10.1007/ s11481-021-10015-6.

Supriya D. Mahajan

smahajan@buffalo.edu

1 Department of Medicine, Division of Allergy, Immunology \& Rheumatology Jacobs School of Medicine and Biomedical Sciences, Clinical Translational Research Center, University At Buffalo, Buffalo, NY 14203, USA

2 Department of Pharmacology \& Therapeutics Roswell Park Comprehensive Cancer Center, Buffalo, NY 14263, USA

3 Department of Physics, University At Albany SUNY, 1400 Washington Avenue, Albany, NY 12222, USA 